\title{
Physicochemical Quality Assessment of Salt-Free Fermented Fish Products of Sylhet Region, Bangladesh
}

\author{
M.B.H. Sikder ${ }^{1,2^{*}}$, I. Ahmed ${ }^{1}$, S.S. Rashid ${ }^{2}$ and A.N.M. Ramli ${ }^{2}$ \\ ${ }^{\prime}$ Department of Food Engineering and Tea Technology, Shahjalal University of Sciences and Technology, \\ Sylhet-3114, Bangladesh. \\ ${ }^{2}$ Faculty of Industrial Sciences and Technology, Universiti Malaysia Pahang, Gambang 26300, Pahang, \\ Malaysia. \\ ${ }^{*}$ Email: belalustc@yahoo.com
}

\begin{abstract}
Shidals are popular salt-free fermented fish foodstuffs in Sylhet area of Bangladesh due to its distinctive flavor and taste. In this study, the proximate composition, physicochemical and antioxidative potential had been studied of three kinds of shidals prepared from punti (Puntius sophore), kangla (Notopterus notopterus) and bashpata (Setipinna phasa) available in the local markets. The results of investigation suggested that shidals are a good source of protein content ranging from $30.49 \%$ to $38.27 \%$. The $\mathrm{pH}$, moisture, crude fat, ash and carbohydrate content ranged from $6.09 \%-6.74 \%$, $34.46 \%-35.33 \%, 17.48 \%-21.43 \%, 06.31 \%-13.05 \%$ and $1.20 \%-1.73 \%$ correspondingly. 2,2-diphenyl1-picrylhydrazyl (DPPH) radical scavenging activity of punti, kangla and bashpata shidals was found $68.13 \pm 2.45,53.95 \pm 1.52$ and $73.88 \pm 1.21$, respectively. Total Volatile Base Nitrogen (TVB-N) content ranged from $37.57-57.92 \mathrm{mg} .100 \mathrm{~g} \mathrm{~g}^{-1}$. This finding suggested that the fermented fish products is a good source of nutrient for the local peoples.
\end{abstract}

Indexed Terms- Antioxidant activity, fermented fish, scavenging activity, Shidals.

\section{INTRODUCTION}

Fermentation of some local fishes is one of the oldest and indigenous techniques for the processing, preservation, and consumption in Bangladesh. Like many other Southeast Asian countries, in the Sylhet region of Bangladesh, the preservation of fish products by fermentation is commonly practiced [1] Traditionally, fermented fish products are widely consumed because of their characteristic taste and smell as well as rich nutritional profile. Indigenous people in this region use native fermented fish products to provide the basic components of their diet, with various features of nutrition, flavor, palatability and texture [2]. Enhanced flavor, digestibility and therapeutic value have been reported in fermented fish products with improved nutritional and functional properties [3-6]. Consumption of fermented fishes introduces and balances beneficial bacteria into the digestive tract for higher nutrients absorption of the nutrients by regulating enough digestive enzymes [7]. The bioactive peptides are yielded by the breakdown of fish proteins by microbial or indigenous proteases, thus, substantially increasing biological properties of the food [8]. Various biological activities, such as antithrombotic and antioxidative activities, cholesterol-lowering ability, blood-pressure lowering effects and antimicrobial properties have been observed in peptides released from the proteins of fermented fishes. Because of all of these reasons, high priority has been given by the WHO food safety unit for the research in fermented fish products [9]. Shidals are fermented fish products without salts in Eastern Bangladesh and Northeast India. Shidals are generally prepared from punti (Puntius sophore), kangla (Notopterus notopterus) and bashpata (Setipinna phasa), three indigenous fishes of Bangladesh [1]. Their distinct strong flavor has made them very popular. The typical strong smell of shidal can be attributed from the conversion of fish proteins and lipids, which produce a variety of peptides, amino acids, fatty acids, indole, skatole, etc. [10]. Their shape remains almost unaltered, but a few cleavages may be observed sometimes around the portions of stomach and tail. Dull white color in shidal indicates 
the product of best quality. If they are exposed to air continuously, the color may turn brownish. The old-aged technology of shidal preparation originated in Bangladesh. The month of November to February is the usual time span for shidal production [9]. Dried salt-free punti, kangla or bashpata are generally used and the fermentation occurs in earthen cans (called "matka" in Bengali). These fermented fish products can be produced simply but production of better-quality yields requires expertise [1]. Existence of essential fatty acids has made shidals nutritionally enhanced food product [9]. It has been suggested by some of researchers that salt-free fermented fish like shidals can be considered as a prospective sources of nutrients and natural antioxidants $[10,11]$. Various studies have been reported on different fermented fish products throughout the past years. "-Kasef, a traditional salted-fermented fish product of Jazan region, Saudi Arabia have been studied. The identification of dominant microbial communities in hongeo samples provides important information for selection of fermented fish products consisting of strains. Physicochemical properties and bacterial community dynamics of hongeo, a Korean traditional fermented skate product, during fermentation at $10^{\circ} \mathrm{C}$ have been investigated" [12]. "Microbiological and chemical quality of Hout" [13]. Although some reports are available on the traditional knowledge, handling and processing of shidals, no thoughtful effort has been made to assess the physicochemical qualities of punti, kangla and bashpata shidals to till date to the first-rate of our understanding. Hence, this study has been conducted to study the physiochemical as well as the antioxidant activity of three traditional salt-free fermented fish products of Sylhet are of Bangladesh, known as shidals, made form punti (Puntius sophore), kangla (Notopterus notopterus) and bashpata (Setipinna phasa) fishes.

\section{MATERIALS AND METHODS}

This research work was carried at the laboratory of Food Engineering and Tea Technology; Chemical Engineering and Polymer Sciences department, Shahjalal University of Science and Technology, Sylhet, Bangladesh.

\subsection{Chemicals}

Hydrochloric acid $(\mathrm{HCl})$, tris- $\mathrm{HCl}$, sulphuric acid $\left(\mathrm{H}_{2} \mathrm{SO}_{4}\right)$, sodium hydroxide $(\mathrm{NaOH})$, potassium ferric cyanide, ferric chloride, tricholoroacetic acid (TCA), thio-barbituric acid (TBA), 2,2-diphenyl-1picrylhydrazyl (DPPH) analytical grade.

\subsection{Traditional Shidal Preparation Method}

Traditional methods of shidals preparation are shown in figure 1.

\subsection{Samples Collection}

A total of $3 \mathrm{~kg}$ of shidal samples prepared from punti (Puntius sophore), kangla (Notopterus notopterus) and bashpata (Setipinna phase) were procured from three different vendors in local shops of Sylhet, Bangladesh. One kg of samples from each variety of shidals namely punti, kangla and bashpata (figure 2) were wrapped in three separate sterile polybags and taken to the laboratory for physicochemical evaluation.

\subsection{Preparation of Sample Extract}

Sample extract was prepared by the method followed by Majumder et al. [9]. Five grams of punti, kangla and bashpata shidal samples was separately mixed with $25 \mathrm{ml}$ of distilled water; the mixture was homogenized at the rate of $12,000 \mathrm{rpm} / \mathrm{min}$. Then this shaked at $110 \mathrm{rpm} / \mathrm{min}$ on shaker for $40 \mathrm{~min}$ at $30^{\circ} \mathrm{C}$. Afterwards the samples were centrifuged at $7000 \mathrm{rpm} / \mathrm{min}$ for $15 \mathrm{~min}$ at $4^{\circ} \mathrm{C}$ to take away unwanted particles. The accrued supernatant taken into consideration for physicochemical testing. 


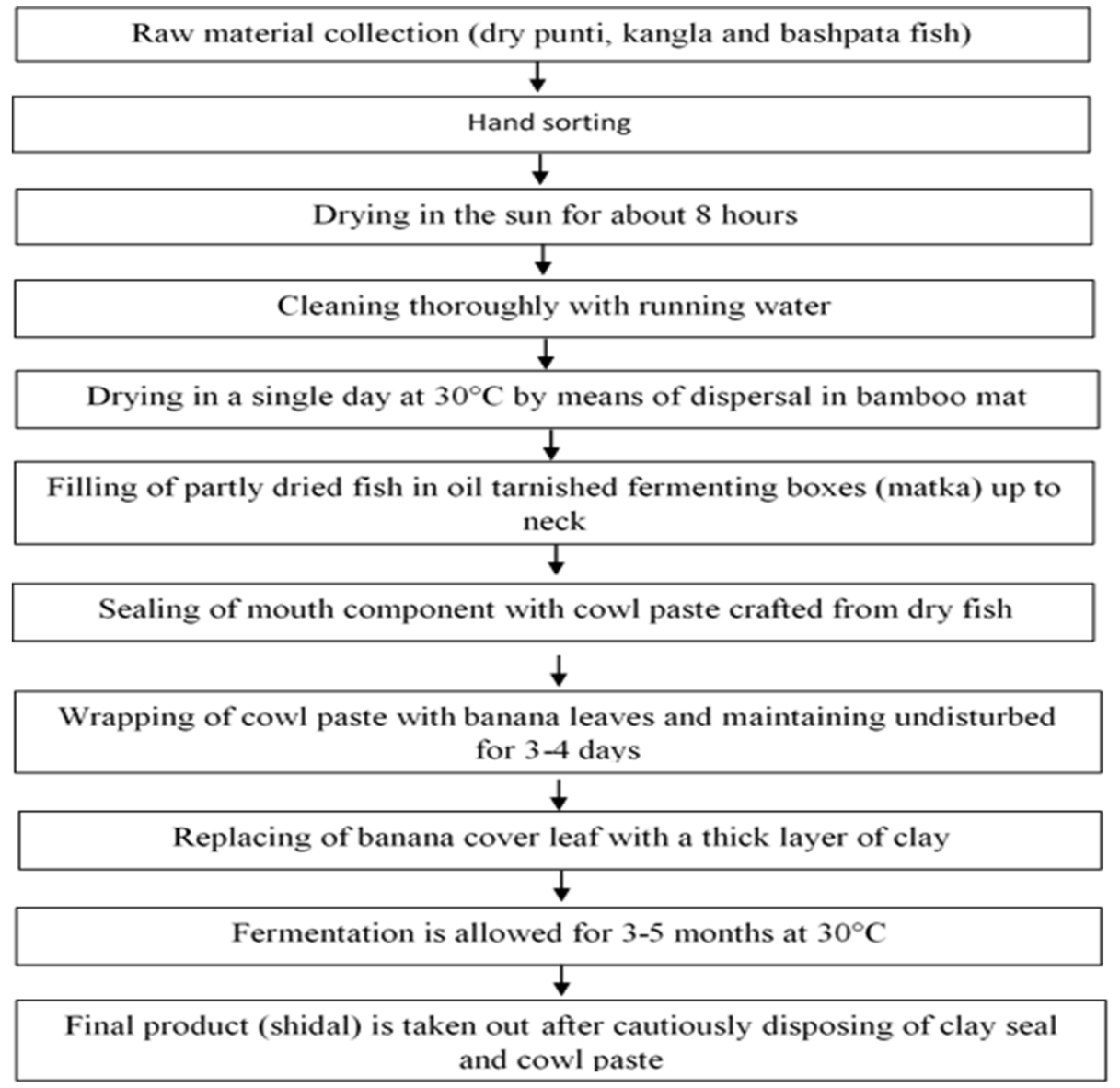

Figure 1: Traditional methods of shidals preparation

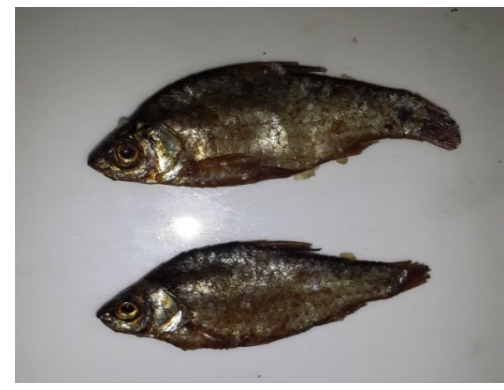

(a) Punti (Puntius sophore) shidal

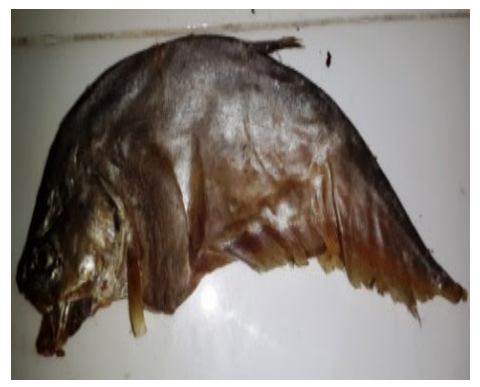

(b) Kangla (Notopterus notopterus) shidal

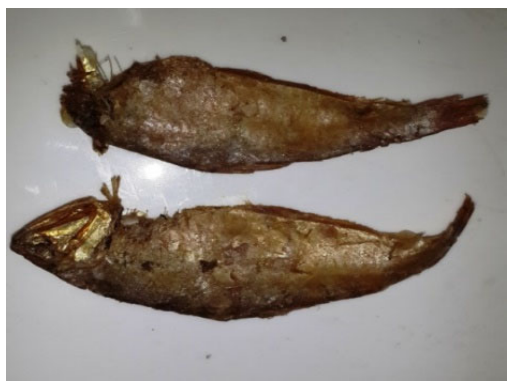

(c) Bashpata (Setipinna phasa) shidal

Figure 2: Salt-free fermented fish product 'shidal' made from (a) punti (Puntius sophore), (b) kangla (Notopterus notopterus) and (c) bashpata (Setipinna phasa), after collecting from local market.

\subsection{Physicochemical Analysis}

2.5.1 Proximate Analysis 
Moisture, crude fat, protein, ash and carbohydrate content material of the shidals had been estimated in keeping with the methods of AOAC [14]. The moisture content was determined from the sample's weight loss $(5.0 \mathrm{~g})$ after being oven-dried for 2 hours at $105^{\circ} \mathrm{C}$ before normal weight was reached. Via an extraction technique using petroleum ether and protein analyzed using the Kjeldahl process, fat content was measured. The conversion content of nitrogen to crude protein was based on factor 6.25 . Ash content material was decided from the load of the pattern burned at $550^{\circ} \mathrm{C}$ for $4 \mathrm{~h}$. Carbohydrate content was assessed from the following equation (Equation 1).

Percentage of Carbohydrate $=(100 \%-$ Protein - Fat - Moisture - Ash $)$

2.5.2 Determination of $\mathrm{pH}$, total volatile base nitrogen (TVB-N) and DPPH radical-scavenging activity

The $\mathrm{pH}$ was determined by Digital $\mathrm{pH}$ meter (JENWAY-3015 $\mathrm{pH}$ meter). $15.0 \mathrm{~g}$ of sample had been blended in $150 \mathrm{ml} \mathrm{DW}$ for two min on high speed in a warring blender. The $\mathrm{pH}$ of the suspension was measured. The TVB-N content was measured by slightly modified method described by Gassem [13]. $10 \mathrm{~g}$ of sample was blended in $50 \mathrm{ml} \mathrm{DW}$; the blender was washed with $250 \mathrm{ml} \mathrm{DW}$ into the distillation flask and 1.0 to $2.0 \mathrm{~g}$ of $\mathrm{MgO}$ become delivered to the mixture. TVB-N turned into launched by means of boiling the aggregate with $\mathrm{MgO}$, which averted volatile acids from distilling over into the boric acid. The distillate of unstable nitrogen changed into acquired in $25 \mathrm{ml}$ of boric acid $2.0 \%$ then titrated by using $0.1 \mathrm{~N}$ sulfuric acid. The results were calculated using the following equation (Equation 2):

TVN-N $(\mathrm{mg} \mathrm{N} / 100 \mathrm{~g})=$ Titration $(\mathrm{ml}$ of $0.1 \mathrm{~N}$ acid $) \times 1$

Antioxidant activity of the punti, kangla and bashpata shidals were determined with modification [9]. One gram of sample was mixed in $9.0 \mathrm{ml}$ of $100 \mathrm{mM}$ Tris-HCl buffer (pH 7.4). Then this solution was nicely mixed, centrifuged at $7000 \mathrm{rpm} / \mathrm{min}$ for $10 \mathrm{~min}$ at $30^{\circ} \mathrm{C}$. A regarded quantity of supernatant was taken and delivered with same quantity of DPPH solution $(0.5 \mathrm{mM}$ in ethanol). The combination turned into left to settle for $30 \mathrm{~min}$ at dark condition. Absorbance was measured at $517 \mathrm{~nm}$ using a UVspectrophotometer (Shimadzu Corporation, Japan).

\subsection{Statistical Analysis}

Experiments were performed twice, and all measurements have been executed in triplicate. Values had been expressed as mean \pm standard deviation (SD) and analyzed using one-way analysis of variance. Mean contrast changed into carried out using Duncan's more than one variety test and sizable difference became described at $\mathrm{p}<0.05$.

\section{RESULTS AND DISCUSSIONS}

\subsection{Proximate composition}

The mean values of proximate composition of fermented fish products made from punti (Puntius sophore), kangla (Notopterus notopterus) and bashpata (Setipinna phasa) are given in table 1. The highest moisture content $35.33 \pm 1.29 \%$ was found in kangla shidal and lowest $34.46 \pm 0.35 \%$ was found in punti shidal. There is no significant different in moisture content among three samples. These findings is supported with the report of Kakati and Goswami, who found that punti and bashpata shidal contained $33.44 \%$ and $37.52 \%$ respectively [11]. The higher moisture content in those shidals may be because of the possible absorption of moisture from the environment at storage, considering that in maximum locations shidal is stored in earthen pots or in plastic bottles during supply chain [2]. The highest crude fat content was found to be $21.43 \pm 0.68 \%$ in punti shidal and lowest was found to be $17.48 \pm 0.48 \%$ in kangla shidal. 
Table 1: Proximate composition of fermented fish products made from punti (Puntius sophore), kangla (Notopterus notopterus) and bashpata (Setipinna phasa).

\begin{tabular}{llll}
\hline Parameters & Punti & Kangla & Bashpatha \\
\hline Moisture (\%) & $34.46 \pm 0.35$ & $35.33 \pm 1.29$ & $35.31 \pm 0.94$ \\
Crude fat (\%) & $21.43 \pm 0.68$ & $17.48 \pm 0.48$ & $18.38 \pm 0.55$ \\
Protein (\%) & $30.49 \pm 1.33$ & $33.28 \pm 0.99$ & $38.27 \pm 0.59$ \\
Ash (\%) & $12.12 \pm 0.63$ & $13.05 \pm 0.76$ & $6.31 \pm 0.58$ \\
Carbohydrate (\%) & $1.49 \pm 0.47$ & $1.20 \pm 0.65$ & $1.73 \pm 0.74$ \\
\hline
\end{tabular}

Note: Data given are mean \pm standard deviation for three different value of each sample. Values denoted with the different letter within the same rows are significantly $(\mathrm{p} \leq 0.05)$ different.

The difference of the fat contents among the three shidal samples might be contributed to the lipid content of the raw fish. Similar fat content was reported by some researchers for fermented fish products [11]. Protein contents of the shidal ranged from $30.49 \pm 1.33 \%$ to $38.27 \pm 0.59 \%$. The highest protein content was found to be $38.27 \pm 0.59 \%$ in bashpata shidal and lowest protein content was found to be $30.49 \pm 1.33 \%$ in punti shidal. There is a significant different of protein content among three samples. Increasing the protein, fat content material of the product may be attributed to the reduction of moisture contents. From this result, it is revealed that fermented fish products are good sources of protein and fat. Similar findings were reported by another researcher for fermented fish products [11]. Ash contents of the shidals were within the range of $6.31 \pm 0.58 \%$ to $13.05 \pm 0.76 \%$. The highest ash content was found to be $12.12 \pm 0.63 \%$ in punti shidal while lowest ash content was found to be $6.31 \pm 0.58 \%$ in bashpata shidal. Very small amount of carbohydrates within the range of $1.20 \pm 0.65 \%$ to $1.73 \pm 0.74 \%$ was observed in the fermented fish products. The highest carbohydrate content was found to be $1.73 \pm$ $0.74 \%$ in bashpata shidal while the lowest carbohydrate content was observed to be $1.20 \pm 0.65 \%$ in kangla shidal. An overall comparison of proximate composition among different fermented fish product is shown in Figure 3.

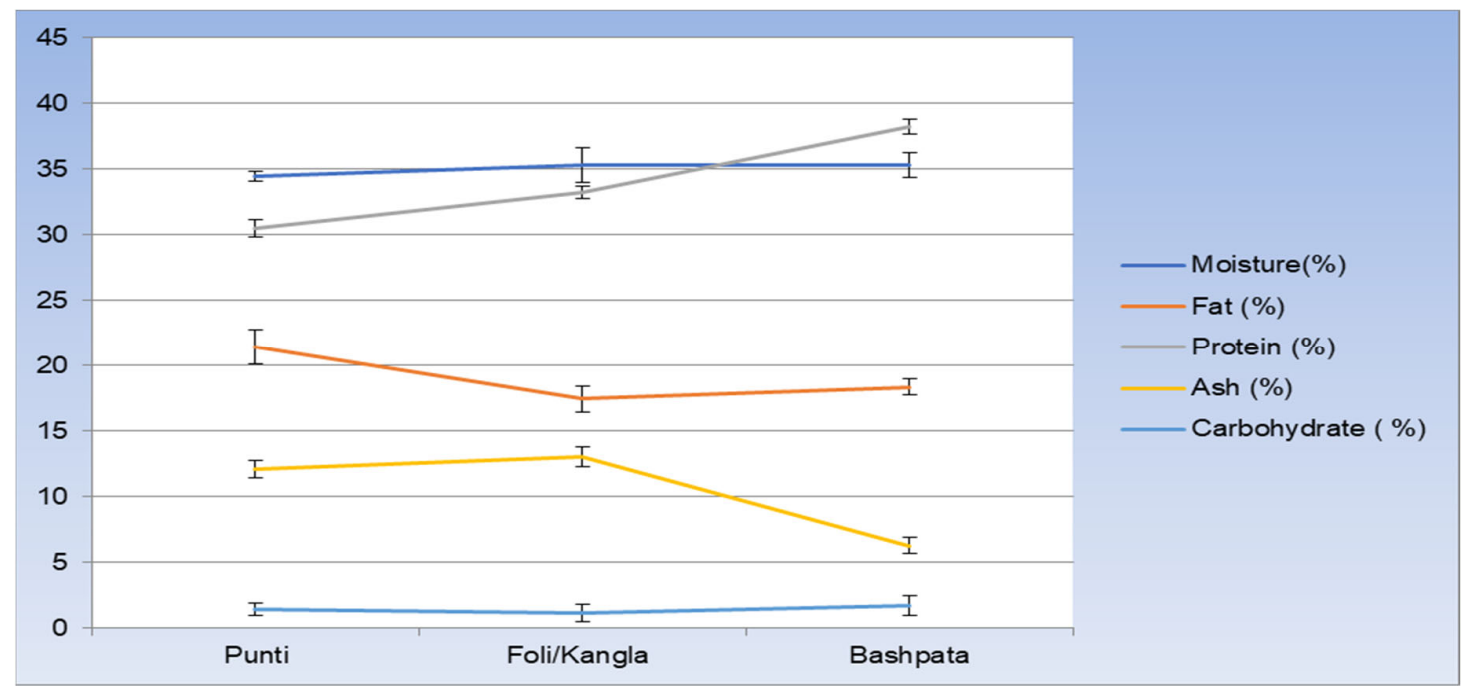

Figure 3: Comparison in proximate composition among different fermented fish. 


\section{$3.2 \mathrm{pH}$, total volatile base nitrogen (TVB-N) content and DPPH radical scavenging activity (\%)}

The $\mathrm{pH}$, total volatile basic nitrogen (TVB-N) content and DPPH radical scavenging activity (\%) of fermented fish product are given in Table 2.

Table 2: $\mathrm{pH}$, total volatile basic nitrogen (TVB-N) content and DPPH radical scavenging activity (\%) of fermented fish made form Punti (Puntius sophore), Kangla (Notopterus notopterus) and Bashpata (Setipinna phasa).

\begin{tabular}{lcrr}
\hline Parameters & Punti & Kangla & Bashpatha \\
\hline $\mathrm{pH}$ & $6.74 \pm 0.02$ & $6.09 \pm 0.15$ & $6.12 \pm .02$ \\
TVB-N (mg/100g) & $45.61 \pm 0.67$ & $37.57 \pm 0.51$ & $57.92 \pm 0.59$ \\
DPPH radical scavenging activity (\%) & $68.13 \pm 2.45$ & $53.95 \pm 1.52$ & $73.88 \pm 1.21$ \\
\hline
\end{tabular}

Data given are mean \pm standard deviation for three different value of each sample. Values denoted with the different letter within the same row are significantly $(\mathrm{p} \leq 0.05)$ different.

The $\mathrm{pH}$ value of shidal samples ranged from $6.09 \pm 0.15$ to $6.74 \pm 0.02$. The $\mathrm{pH}$ of punti shidal appeared to be a little higher with respect to other shidals, but this may be owing to the higher amount of volatile nitrogenous compound production during fermentation that accumulated in punti shidal. Similar results were observed by other scientist Kakati and Goswami, who reported that the $\mathrm{pH}$ values of punti and bashpata shidal were 6.10 and 6.20 respectively [11]. The content of TVB-N of the product is the signs of excessive fermentation [13]. The TVB-N values of the shidals ranged from $37.57 \pm 0.51 \mathrm{mg} / 100 \mathrm{~g}$ to $57.92 \pm 0.59 \mathrm{mg} / 100 \mathrm{~g}$, indicating the degradation of tissue protein responsible to produce the typical flavor and aroma of shidals. The TVB-N content was found to be $45.61 \pm 0.67 \mathrm{mg} / 100 \mathrm{~g}, 37.57 \pm 0.51$ $\mathrm{mg} / 100 \mathrm{~g}$ and $57.92 \pm 0.59 \mathrm{mg} / 100 \mathrm{~g}$ in punti, kangla and bashpatha shidals, respectively. These results are consistent with the reports made by some authors [11, 15]. Similar TVB-N values were reported by Sarojnalini and Suchitra in ngari, a local fermented fish found in the Manipur State of India [16]. TVB$\mathrm{N}$ in fermented fish product do not contribute to the formation of any ammonia-like odor in fermented fish products indicating that the punti, kangla and bashpata shidals investigated in this study were supported by Majumdar et al. [2]. DPPH radical scavenging activity of punti kangla and bashpatha shidal was determined as $68.13 \pm 2.45 \%, 53.95 \pm 1.52 \%$ and $73.88 \pm 1.21 \%$ respectively (table 2 ). The highest DPPH radical scavenging activity was found to be $73.88 \pm 1.21 \%$ in bashpatha shidal while the lowest DPPH radical scavenging activity was observed at $53.95 \pm 1.52 \%$ in kangla shidal. Higher DPPH radical scavenging activity reveals the high contents of antioxidants in the fermented fish products. These results are supported with the reports made by some others researchers [5, 13]. It is well recognized that the bioactive agents from our diet can inhibit the effects caused by oxidative stress [17]. Therefore, punti, kangla and bashpata shidals may be considered as health-food from the observed protein, fat content and DPPH radical scavenging activity.

\section{CONCLUSION}

The present study revealed that punti, kangla and bashpata shidals (fermented fish products) possess a high nutritive value and antioxidative properties. Therefore, it can be concluded that punti, kangla and bashpata shidals, three salt-free fermented fish products of Sylhet region of Bangladesh are potential sources of nutrients and natural antioxidants. 


\section{Acknowledgements}

The authors express their appreciation to the Department of Food Engineering and Tea Technology, Shahjalal University of Science and Technology, Sylhet for chemicals supply and practical assistance.

\section{Conflicts of Interest}

The authors confirmed no conflicts of interest among them.

\section{REFERENCES}

[1] Nayeem M. A., Pervin K., Reza M. S., Khan M. N. A., Shikha F. H., and M. K. "Present status of handling, transportation and processing of traditional dried Punti (punti shutki) and semifermented fish (chepa shutki) products in Mymensingh district, Bangladesh". Journal of Agroforestry Environment. 4(1): 13-16, 2010.

[2] Majumdar R. K., Roy D., Bejjanki S., and N. B. "An overview of some ethnic fermented fish products of the Eastern Himalayan region of India". Journal of Ethnic Foods. 3(4): 276-283, 2016.

[3] Bjerke G. A., Rudi K., Avershina E., Moen B., Blom H., and Axelsson L. "Exploring the Brine Microbiota of a Traditional Norwegian Fermented Fish Product (Rakfisk) from Six Different Producers during Two Consecutive Seasonal Productions.". Foods. 8(2): 72, 2019.

[4] Rahimnejad S., Lu K., Wang L., Song K., Mai K., Davis D. A., and Zhang C. "Replacement of fish meal with Bacillus pumillus SE5 and Pseudozyma aphidis ZR1 fermented soybean meal in diets for Japanese seabass (Lateolabrax japonicus)". Fish and Shellfish Immunology. 84: 987997., 2019.

[5] Singh S. S., De Mandal S., Lalnunmawii E., and Senthil K. N. "Antimicrobial, antioxidant and probiotics characterization of dominant bacterial isolates from traditional fermented fish of Manipur, North-East India.". Journal of Food Science and Technology. 55(5): 1870-1879, 2018.

[6] Zang J., Xu Y., Xia W., and Regenstein J. M. "Quality, functionality, and microbiology of fermented fish: a review". Critical Review of Food Science and Nutrition. . 60(7): 1228-1242, 2020.

[7] Hyun Y. J., Piao M. J., Kang K. A., Zhen A. X., Madushan Fernando P. D. S., Kang H. K., and Hyun J. W. "Effect of fermented fish oil on fine particulate matter-induced skin aging.". Marine drugs. 17(1): 61, 2019.

[8] Cao S. M., Wu Y. Y., Li L. H., Yang X. Q., Chen S. J., Hu X., and Ma H. X. "Activities of endogenous lipase and lipolysis oxidation of low-salt lactic acid-fermented fish (Decapterus maruadsi).". Journal of oleo science. 67(4): 445-453., 2018.

[9] Majumdar R. K., Roy D., Bejjanki S., and Bhaskar N. "Chemical and microbial properties of shidal, a traditional fermented fish of Northeast India". Journal of Food Science and Technology. 53(1): 401-410, 2016.

[10] Muzaddadi A. U. and Basu S. "Shidal-a traditional fermented fishery product of North East India". Indian Journal of Traditional Knowledge. 11(2): 323-328, 2012.

[11] Kakati B. K. and Goswami U. C. "Characterization of the traditional fermented fish product Shidol of Northeast India prepared from Puntius sophore and Setipinna phasa". Indian Journal of Traditional Knowledge. 12: 85-90, 2013.

[12] Zhao C.-C., Kim D.-W., and Eun J.-B. J. L. "Physicochemical properties and bacterial community dynamics of hongeo, a Korean traditional fermented skate product, during fermentation at $10^{\circ} \mathrm{C}$. LWT. 104: 109-119, 2019.

[13] Gassem M. A. "Microbiological and chemical quality of a traditional salted-fermented fish (HoutKasef) product of Jazan Region, Saudi Arabia. ". Saudi Journal of Biological Science. 26(1): 137140, 2019.

[14] International A. "Aromatic intermediates and derivatives. In Latimar G W (ed.) Official Methods of Analysis of AOAC International. Washington DC U. A. o. O. A. C., 
[15] Roy D., Majumdar R., Maurya S. K., Tripathi H. H., Dhar B., and M. P. B. "Understanding of traditional knowledge and characterization of telesech-a fermented fish product of Tripura state". Indian Journal of Natural Products and Resources. 5(4): 351-358, 2015.

[16] Sarojnalini C. and Suchitra T. "Microbial profile of starter culture fermented fish product'Ngari'of Manipur". Indian Journal of Fish. 56(2): 123-127, 2009.

[17] Vo T. and Park J. H. "Characteristics of Potential Gamma-Aminobutyric Acid-Producing Bacteria Isolated from Korean and Vietnamese Fermented Fish Products.". Journal of Microbiology Biotechnology. 29(2): 209-221, 2019. 